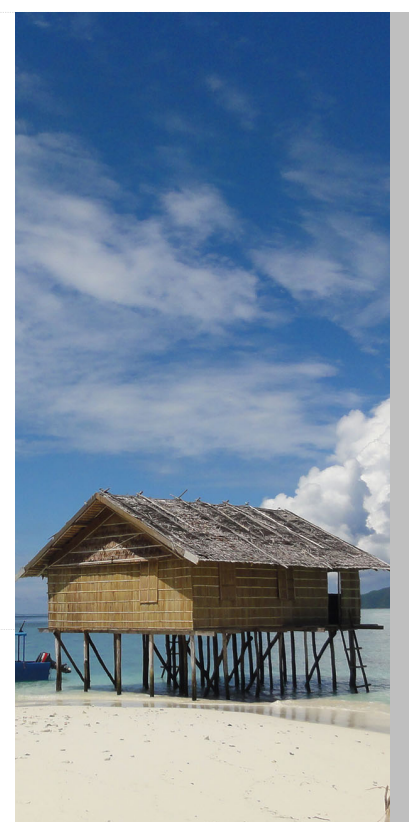

\title{
NATIONAL PARK ENTRANCE FEES: A GLOBAL BENCHMARKING FOCUSED ON AFFORDABILITY
}

\author{
Hugo Van Zyl ${ }^{1^{*}}$, James Kinghorn ${ }^{1}$ and Lucy Emerton ${ }^{2}$ \\ *Corresponding author: hugo@independentecon.co.za \\ ${ }^{1}$ Independent Economic Researchers, Cape Town, South Africa. Orcid.org/0000-0002- \\ 2810-1167 \\ 2 Independent Economic Researchers, Cape Town, South Africa. Orcid.org/0000-0002- \\ 6465-4295 \\ ${ }^{3}$ Environment Management Group, Cambridge, UK and Colombo, Sri Lanka
}

\begin{abstract}
Setting protected area entrance fees at appropriate levels can be extremely challenging. We provide benchmarking data across a sample of 62 countries and construct an Index of Affordability (IOA), showing protected area entry fees relative to citizens' per capita income adjusted for purchasing power. Using this measure, Australian parks are the most affordable (IOA of 0.10) to citizens, those in Benin are the least affordable (10.69), while Indonesia is closest to the global average IOA of 2.09. Protected areas in low-income countries are on average 30 times less affordable to citizens than in high-income countries. This has equity implications, and may supress visitation rates, thereby reducing the degree to which citizens attach value to, and are willing to support, national parks. International tourist fees are lowest in Armenia (US\$1.04) and highest in Tanzania (US\$43.72), while Costa Rica is closest to the global average (US\$11.21), a relatively small proportion of the US\$165 average daily spend estimated for European middle to higher income tourists. International tourists to low-income countries pay an average entrance fee of US\$20, four times that paid in high-income countries. This is arguably fair, given their far smaller protected area funding bases and much greater reliance on tourism earnings. Our findings support fee differentiation between citizens and international tourists as a means of equating affordability.
\end{abstract}

Key words: Protected area entrance fees, fee setting, benchmarking, affordability, global review, protected area financing

\section{INTRODUCTION}

Globally, it is estimated that protected areas receive around eight billion visits every year, generating as much as US\$600 billion of spending and US\$250 billion in consumer surplus (Balmford et al., 2015). The level and structure of entrance fees can have a pivotal influence on the financial success of protected areas (PAs) as well as their accessibility and perceived social value. Setting them appropriately, when done thoughtfully, involves the careful balancing of numerous competing objectives. For example, management costs need to be covered and revenues optimised without losing sight of affordability considerations especially for citizens (whose tax payments contribute to protected area funding in the majority of cases). At the same time, pricing is often used as a tool to manage protected area visitor numbers, meaning that relative price levels in other sites (or even countries) are a consideration. Aside from the inherent challenges associated with balancing numerous (sometimes competing, or even conflicting) objectives, protected area managers often have limited guiding information at their disposal to set prices. Filling information gaps can be time consuming and expensive. Among other information, benchmarking data on comparable entrance fees in other countries can be very helpful in assisting with fee setting especially if it is presented in a way that allows for an understanding of the relative affordability of fees in other countries. However, such benchmarking data is generally lacking or not well developed. This article aims to assist in this regard.

Funding shortages are one of the most important barriers to the achievement of the conservation objectives of PAs. Bruner et al. (2001) demonstrate that an increase in funding is the most effective way of ensuring that protected area managers can adequately 
mitigate against land clearing and other threats to biodiversity. The indirect or non-market nature of many of the costs and benefits associated with protected areas makes it challenging to make the case for public funding allocations or to consider protected areas in purely commercial terms (Dixon \& Sherman, 1991; Walpole et al., 2001). This is especially true in the developing world, where pressing development needs provide strong competition for scarce government resources (Inamdar et al., 1999; Krug, 2000). Shortfalls in funding available to protected areas in the developing world are well documented (see Adams et al., 2008; Bruner et al., 2004). In extreme cases, where these shortfalls are acute, they have resulted in the existence of paper parks - areas which have been set aside for conservation but where no real management occurs (Eagles, 2013).

In most countries, protected areas still depend primarily on government funding, sometimes supplemented with grants and donations from nongovernmental organisations, development donors, the general public or the business sector. In Latin America, for example, public budgets account for about 60 per cent of protected area available funding (Flores \& Bovarnick, 2016). Yet, not only is this narrow financial base typically totally inadequate to ensure effective conservation management, it is also insecure and risky (Emerton et al., 2006). In Montenegro, for example, not only has public funding to protected areas been steadily falling over time, it is also only sufficient to cover around a half of the estimated costs of basic protected area management (Emerton et al., 2011). Competing budgetary requirements, combined with increased scarcity of and demand for land have placed growing pressure on protected area managers to both justify the existence of protected areas and to reduce their dependence on scarce public budgets (Edwards \& Abivardi, 1998).

There are essentially two ways that the latter has been achieved by protected area management authorities (MAs), and with varying degrees of success. The first has been to reduce costs and the second is to increase so -called own revenues or self-generated revenue (primarily from entrance fees and tourism concessions and services such as accommodation, tours and restaurants). For the latter, an important consideration is whether these increased revenues can be retained, earmarked and reinvested in conservation activities (Emerton et al., 2006; Berghöfer et al., 2017). MAs have had varying degrees of success with increasing selfgenerated revenues. For example, between 2009 and 2015, the South African National Parks Board (SANParks) were able to grow own revenues strongly at annual rates of about 5 per cent above inflation. By 2016, own revenues contributed roughly 55 per cent to overall SANParks revenues with the rest coming from government allocations and donors (SANParks, 2016). There also remains a significant element of cross subsidisation, with only five out of 19 parks in South Africa generating enough own revenues to cover their costs. By contrast, Lindsey et al. (2014) point out that self-generated revenues from national parks in Zambia have remained low particularly when considered relative to their potential.

This reliance on a combination of self-generated and external budget sources is the norm in most countries: Walpole et al. (2001) reviewed the available studies and found that it was only in a few exceptional circumstances that protected area systems were able to generate sufficient own revenue to cover management costs entirely. Reviews such as that of Bovarnick et al. (2010) demonstrate that self-generated revenue usually forms a relatively small part of overall funding for protected area systems. Furthermore, it is a commonly held view that a vision of 'full' financial self-sufficiency is not only unachievable, but is broadly accepted as being also unsuited to protected areas that are essentially public goods being managed in the broader social, economic and conservation interest (Herath, 2000; Buckley, 2003; Hübner et al., 2014). There is, however, general consensus that protected area revenue bases need to be increased, diversified and expanded in order to generate the funding that is required for effective biodiversity conservation.

Entrance fees are probably the most widely used and easily accessible source of self-generated protected area revenues. In addition to the presence of visitors, there are several factors which can be considered when management authorities are determining entrance fees, and these will vary in importance depending on the context within which fees are being set. Concerning the practical considerations relating to protected area entrance fee setting, Lindberg and Halpenny (2001) argue that too often fees are set purely based on considerations surrounding revenue generation. In addition to how much revenue needs to be generated to ensure that management costs are covered, management authorities should consider the following (Oleas, 2008; Banerjee et al., 2017; Watson, 2013; Eagles et al., 2002):

- $\quad$ Ensuring optimal visitor numbers, both to manage the level of ecological impact within the park and to reduce congestion for the sake of visitor satisfaction

- $\quad$ Encouraging more or fewer visits to surrounding substitute sites, or encourage fewer visits during 
particular times, such as times of heightened ecological sensitivity

- Achieving a social purpose, such as environmental education or ensuring that people have access to places for recreation

- $\quad$ Aligning fees with those of similar attractions and so matching them with public expectations.

PA planners and managers frequently lack data which would allow them to benchmark fees either against other countries, or relative to price levels in their own country. Yet benchmarking can be a useful tool when setting fees of various kinds. For example, Loomis Hubbell et al. (2002) examine the use of benchmarking to assist in decisions around setting tuition fees for universities. Few studies have provided reviews of protected area entrance fees in a format which allows for benchmarking to be carried out. Lindberg and
Halpenny (2001) conducted a global review of protected area entrance fees with a focus on marine protected areas. Spenceley et al. (2017) presented the fees of Tanzanian game reserves and wildlife management areas alongside those charged by national parks, and also looked at fees charged in national parks in South Africa, Botswana, Namibia and Zimbabwe. Given the focus of these papers on marine protected areas and selected African countries respectively, a review of the literature has not revealed any studies which have taken a global perspective on benchmarking terrestrial national park entrance fees.

It should be noted that benchmarking is rarely used in isolation but rather applied alongside other techniques for determining optimal fee levels. It cannot capture essential information about the uniqueness of the protected area 'offering' in a particular country or the

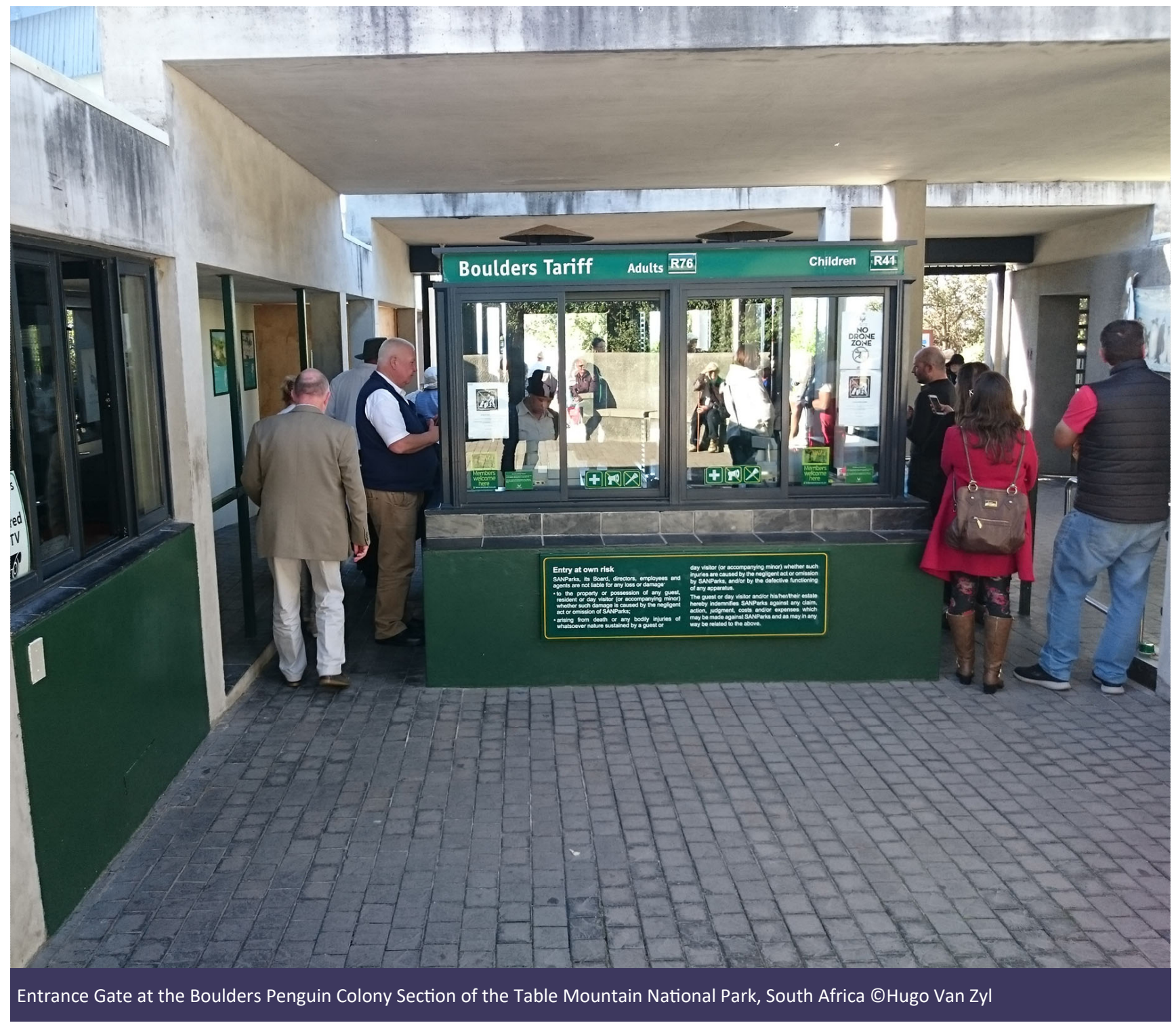


specific characteristics and expectations of visitors that determine their preferences and price points. It is typically used to provide a guide to the initial starting point, or the final point cross-check and validation of the results, of these other studies. Management authorities are increasingly relying on consumer research to determine which fee levels can achieve a balance between public expectations and revenue maximisation. Stated preference techniques (such as contingent valuation and choice experiments) as well as travel cost methods, which look at visitors' willingness to pay, are particularly commonly used to inform protected area pricing. They often also provide information about the potential to introduce other fees, charges or voluntary levies in addition to entrance fees. The issue of consumer surplus is often an important one, as evidenced by the number of studies which have found that people are willing to pay more than the entrance fee that they are charged to enter a given protected area (see review in Spenceley et al., 2017 for examples; Adams et al., 2008; Nogueira \& Salgado, 2001).

Affordability is a central issue to consider when setting protected area entrance fees. This is especially true when considering fees for local community members or citizens of that country, given that they will tend on average to have lower incomes than international visitors. In addition to this, national protected area systems will nearly always be at least partially funded by taxpayers and provide wider societal benefits such as environmental education and recreation, which can be maximised when fees are structured in a way that promotes accessibility to all income levels (whilst ensuring conservation objectives are met). It is often argued that there is a distributional dimension to protected area pricing, especially for those sites that receive visitors from different origins (see, for example, Alpizar, 2006; Mendes, 2003). For this reason, many protected area systems have multi-tier pricing structures, which allow them to accomplish differing objectives for differing groupings of visitors. For example, developing nations might have cost recovery or revenue maximisation as a primary objective when setting fees for international tourists, and maximising the provision of learning opportunities as the main objective for local visitors (Lindberg \& Halpenny, 2001). Another reason that citizens are often charged less than international tourists is that most national park systems are funded primarily or at least partially by the state, and so citizens will already be contributing to their financing in an indirect way. Many protected area systems will also have special prices for children, students, retirees, disabled people and other groups who are deemed to qualify for reduced prices.
The key objectives of the article are to provide hitherto unavailable benchmarking data and analysis of entrance fees in a sample of countries across the globe. The focus is on the relative amounts charged for entrance fees in different countries and the relative affordability of these amounts. This should assist with the review and setting of entrance fees for both citizens and international tourists by management authorities in combination with other considerations, techniques and processes. Note that the article thus does not attempt to 'explain' any entrance fees amounts as this would require a complex dissection of the role played by these considerations, techniques and processes in arriving at a given fee amount. Where appropriate, key factors that seem to be impacting on fees and especially differences between fees are discussed often with significant caveats and to illustrate how selected factors could be playing a role in observed fee amounts thereby hopefully assisting those tasked with setting fees.

\section{METHODS}

The survey focused on National Parks, aiming to ensure that major tourist sites and flagship areas were included (most of which are National Parks) and to increase the level of comparability between countries. While the term 'National Park' corresponds to the International Union for Conservation of Nature (IUCN) Protected Area Management Category II, many countries do not use the term consistently, referring in some cases to protected areas belonging to IUCN Protected Area Management Categories III, V or VI as National Parks. For the purposes of our analysis, only protected areas which correspond to IUCN Protected Area Management Category II were included, regardless of the terminology used by individual countries.

Entrance fee data were gathered for as many countries where such data were reasonably accessible focusing on fees for adult citizens and international tourists in 2018. The primary source for this data was protected area management authority websites, travel blogs, travel information portals and tourism agency websites. Data availability was highly variable between countries. In some instances, it was possible to easily access entrance fee data for all national parks from one source. In others, a number of different sources had to be used. Data coverage was also patchy in relation to the number of national parks per country for which there were data available. Entrance fee data for citizens were found for 51 countries, international tourists' fee data were found for 62 countries while data on both citizen and international tourist entrance fees were available for 51 countries. Countries where entry is free of charge were excluded from the analysis. These include mostly higher 
income countries such as UK, France, Denmark, Sweden, Norway and New Zealand (though the latter are considering the introduction of entrance fees).

The focus on comparisons between countries required the estimation of an average entrance fee for all the parks in a given country. An unweighted average for all national parks was used for this purpose as there is no clear or workable basis for weighting one park more or less than another. This was possible because, on the whole, the variability of fees between individual national parks in the same country was low.

Entrance fees for citizens were converted from local currency amounts to international dollars using purchasing power parity (PPP) exchange rates sourced from the World Bank. Purchasing power parity calculations aim to correct for differences in real price levels between countries. They apply an exchange rate that is based on the rate at which the currency of one country would have to be converted into that of another country to buy the same representative basket of goods. Park entry fees are expressed in international US dollars (Int.\$). An international US dollar has the same purchasing power as the dollar has in the United States and is a commonly accepted numeraire for crosscountry comparisons or aggregations of economic statistics. As international tourists come from a wide variety of countries (which are in most cases not recorded), it is not possible to apply a PPP conversion rate to the fees they pay. Furthermore, as the majority originate from the developed world, it is assumed that there is less variation in purchasing power as compared to international US dollars. Entrance fees for international tourists are therefore expressed in US dollars calculated at market exchange rates.

Entrance fees for citizens were then converted into an index of affordability (IOA) which expresses the protected area entry fee relative to local income levels. This was done by converting the fees into international dollars and dividing them by gross national income (GNI) per person (expressed in PPP \$) sourced from the World Bank. This reflects a common approach taken in studies considering the affordability of products, such as Iyengar et al.'s (2016) comparison of the affordability of hepatitis medication across 30 countries, as well as Murakami and Blom's (2008) global comparison of the affordability of tertiary education. Entrance fees for international tourists were compared to average daily tourist spending to get a sense of their relative cost as compared to total holiday costs.

The chief focus of the study was the benchmarking of national park entrance fees at the country level. To

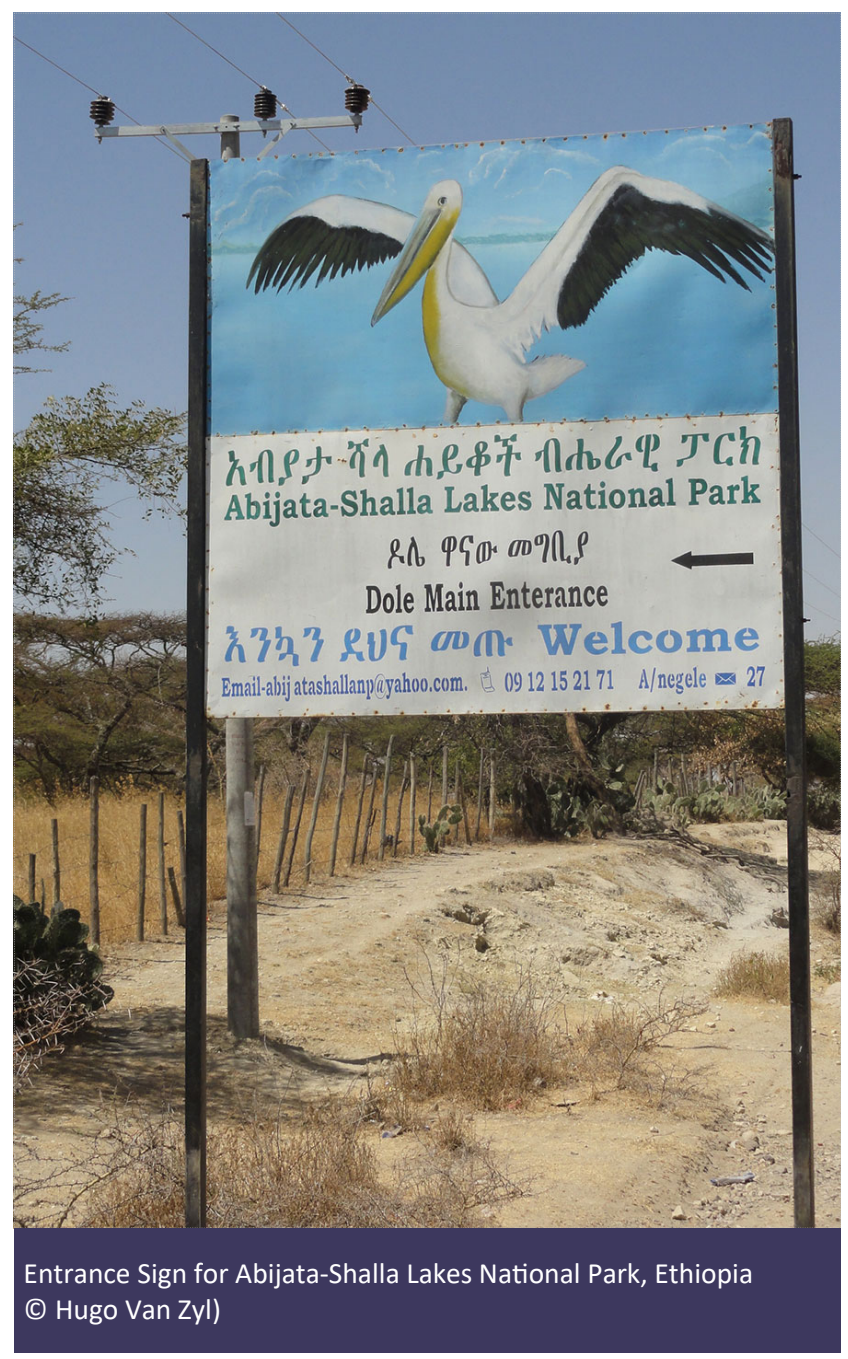

expand on this and explore the data further, two additional analysis components were included which involved grouping countries with similar socioeconomic conditions. The first entailed clustering countries with similar per capita income levels, using the World Bank categorisation of low-income, lower middle-income, upper middle-income and high-income. Countries were also grouped into regions. Alongside geographical proximity, the main criteria were obvious cultural and governance similarities. Russia and China were included individually as they did not fit into any of the other regional groupings.

\section{RESULTS}

Results are presented in two sections. The first focuses on entrance fees for citizens and the second for international tourists. Within each of these sections, results are presented for individual countries as well as for income clusters and regional groups. In each case, results are presented in a way that allows for ranking according to the entrance fee index of affordability for 
citizens and then by the entrance fees charged to international tourists.

\section{Fees for citizens}

A comparison of the affordability of national park entrance fees for citizens in individual countries is provided in Table 1 and its accompanying map in Figure 1. The columns are arranged according to the way the index of affordability was calculated, by taking the fees in market US\$, converting them to international dollars, and then presenting them as a proportion of per capita gross national income for each country (the index of affordability or IOA, expressed in Int. $\$ \times 10^{\wedge} 3$ / Per Capita GNI Int.\$).

The results range from the most affordable fees (IOA of 0.10) for Australia to the least affordable (IOA of 10.69) for Benin. Based on these findings it can be inferred that national park fees are roughly 100 times more affordable for the average local in Australia than they are for the average local in Benin. The average IOA for the 52 countries considered is 2.09 .
The results illustrate the relative impact of purchasing power on affordability. For example, Indonesian citizens are charged an average rate of US $\$ 6.81$ to enter national parks, which is around 60 per cent higher than the global average. When the charge is adjusted to account for Indonesians' purchasing power, it increases to Int.\$ 22.17 which is 120 per cent higher than the global average.

Also shown is the relative impact of income levels. For example, China's average entrance fee in international dollars, Int.\$ 52.49, is the highest of all the countries considered. But when this fee is considered as a proportion of the average Chinese per capita income, China has an IOA of 3.39, making it only the 9th least affordable country of those considered.

When countries are grouped according to their income levels, the results show stark contrasts in the affordability of entrance fees for citizens. Table 2 shows that national parks of low-income countries have an average IOA of 5.25 , which is three times higher than

Index of Affordability (Fee (Int.\$) x 10^3 / Per Capita GNI (Int.\$))

$$
0.10 \quad 10.69 \text { (least affordable) }
$$

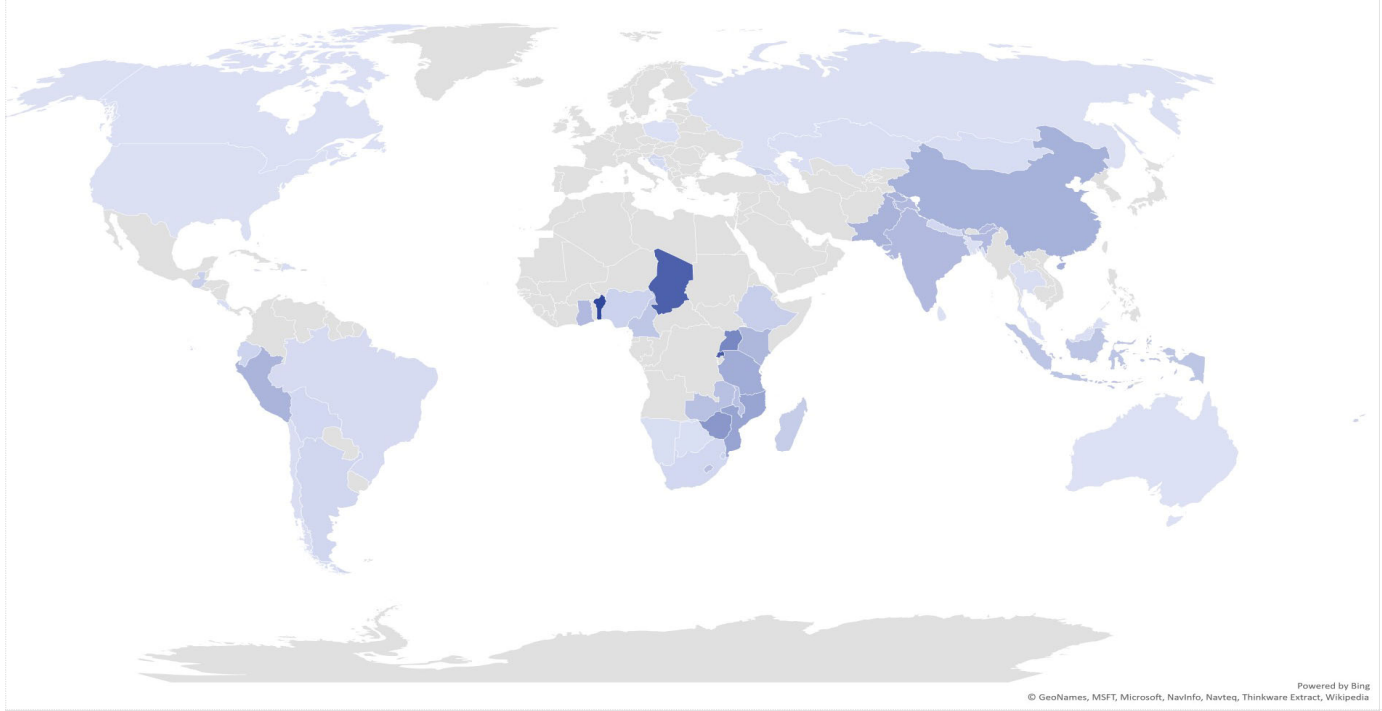

Figure 1 Map of Index of Affordability for citizens per country

Table 2. Affordability of national parks entrance for citizens by income-level groupings

\begin{tabular}{|c|c|c|c|c|c|c|}
\hline Income Group & $\begin{array}{l}\text { Average Fee } \\
\text { US\$ }\end{array}$ & $\begin{array}{l}\text { Average Fee } \\
\text { Int.\$ }\end{array}$ & $\begin{array}{l}\text { Ave PC GNI } \\
\text { (\$/annum) }\end{array}$ & $\begin{array}{l}\text { Index of Affordability (Ave Fee Int.\$ x } 10 \\
\text { Per Capita GNI Int.\$) }\end{array}$ & ^3 / & $\begin{array}{l}\text { Coefficient of } \\
\text { variation }\end{array}$ \\
\hline Low income & 3.33 & 9.11 I & 1756 & & 5.25 & 0.67 \\
\hline Lower middle income & 3.11 & 8.97 & 6829 & & 1.55 & 0.66 \\
\hline Upper middle income & 5.25 & 10.96 & 16319 & & 0.72 & 1.29 \\
\hline High income & 5.46 & 6.42 & 39640 & 口 & 0.17 & 0.41 \\
\hline
\end{tabular}


Table 1. National park entrance fees for international tourists by country

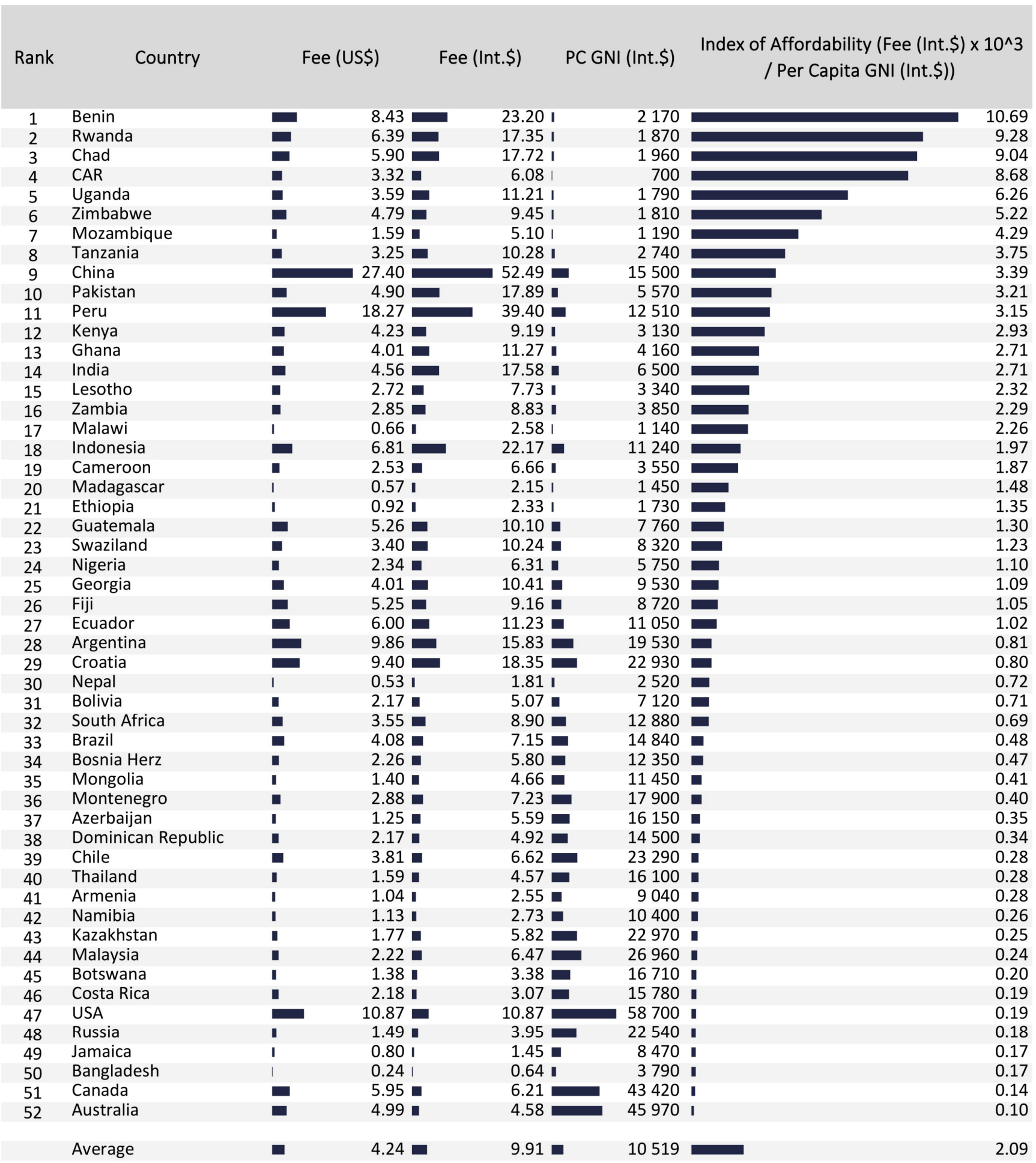

the average IOA of lower middle-income countries (1.55) and 30 times higher than the average IOA of high -income countries (0.17). The coefficient of variation shows how much variation there is between the IOA of the individual countries making up each grouping. It is highest for upper middle-income countries (1.29), very similar for low-income and lower middle-income countries ( 0.67 and 0.66 respectively) and lowest for high-income countries (0.41). Grouping individual countries into regions revealed that Central, West and 
East Africa are the least affordable regions for citizens visiting national parks, while North America, Russia and Central Asia are the most affordable regions (see Table 3). The average IOA for North American countries was 0.16 , while the average for Central African countries was 6.53. From this it can be deduced that the average national park in Central Africa is roughly 40 times less affordable to citizens than is the average national park in North America. The coefficients of variation show that there was relatively more variation in the IOA between the countries of regions such as Southeast Asia and Oceania, and less variation between countries in regions like North America and Central Asia.

\section{Fees for international tourists}

A comparison of the entrance fees charged to international tourists per country is provided in Table 4 and its accompanying map in Figure 2. The cheapest country for international tourists to visit national parks is Armenia, where fees are an average of US\$1.04. The most expensive country is Tanzania, where international tourists are charged an average of US $\$ 43.72$. The average for the 61 countries considered is US $\$ 11.21$ with

Table 3. Affordability of national parks for citizens by regional groupings

\begin{tabular}{|c|c|c|c|c|c|}
\hline Region & Average Fee US\$ & Average Fee Int.\$ & $\begin{array}{l}\text { Ave PC GNI } \\
\text { (\$/ann.) }\end{array}$ & $\begin{array}{l}\text { Index of Affordability (Ave Fee Int.\$ x 10^3 / Per } \\
\text { Capita GNI Int.\$) }\end{array}$ & $\begin{array}{l}\text { Coefficient of } \\
\text { variation }\end{array}$ \\
\hline Central Africa & 3.92 & 10.15 I & 2070 & 6.53 & 0.62 \\
\hline West Africa & 4.93 & 13.59 I & 4027 & 4.83 & 1.06 \\
\hline East Africa & 3.68 & 10.07 I & 2252 & 4.72 & 0.66 \\
\hline China & 27.40 & $52.49 \square$ & 15500 & 3.39 & \\
\hline Southern Africa & 2.26 & 6.11 & 6109 & 2.02 & 0.82 \\
\hline South Asia & 2.12 & 7.84 & 6074 & 1.38 & 1.06 \\
\hline South America & 7.36 & 14.22 & 14723 & 1.08 & 0.97 \\
\hline Southeast Asia & 3.54 & 11.07 & 18100 & 0.83 & 1.19 \\
\hline Oceania & 5.12 & 6.87 & 27345 & 0.57 & 1.17 \\
\hline Caucasus & 2.10 & 6.18 & 11573 & 0.57 & 0.79 \\
\hline Balkans & 4.85 & 10.46 & 17727 & 0.56 & 0.38 \\
\hline CAC* & 2.60 & $4.88 \square$ & 11628 & 0.50 & 1.07 \\
\hline Central Asia & 1.59 & 5.24 & 17210 & 0.33 & 0.33 \\
\hline Russia & 1.49 & 3.95 & 22540 & 0.18 & \\
\hline North America & 8.41 & 8.54 & 51060 & 0.16 & 0.18 \\
\hline
\end{tabular}

*Central America and the Caribbean

Fee (US\$)

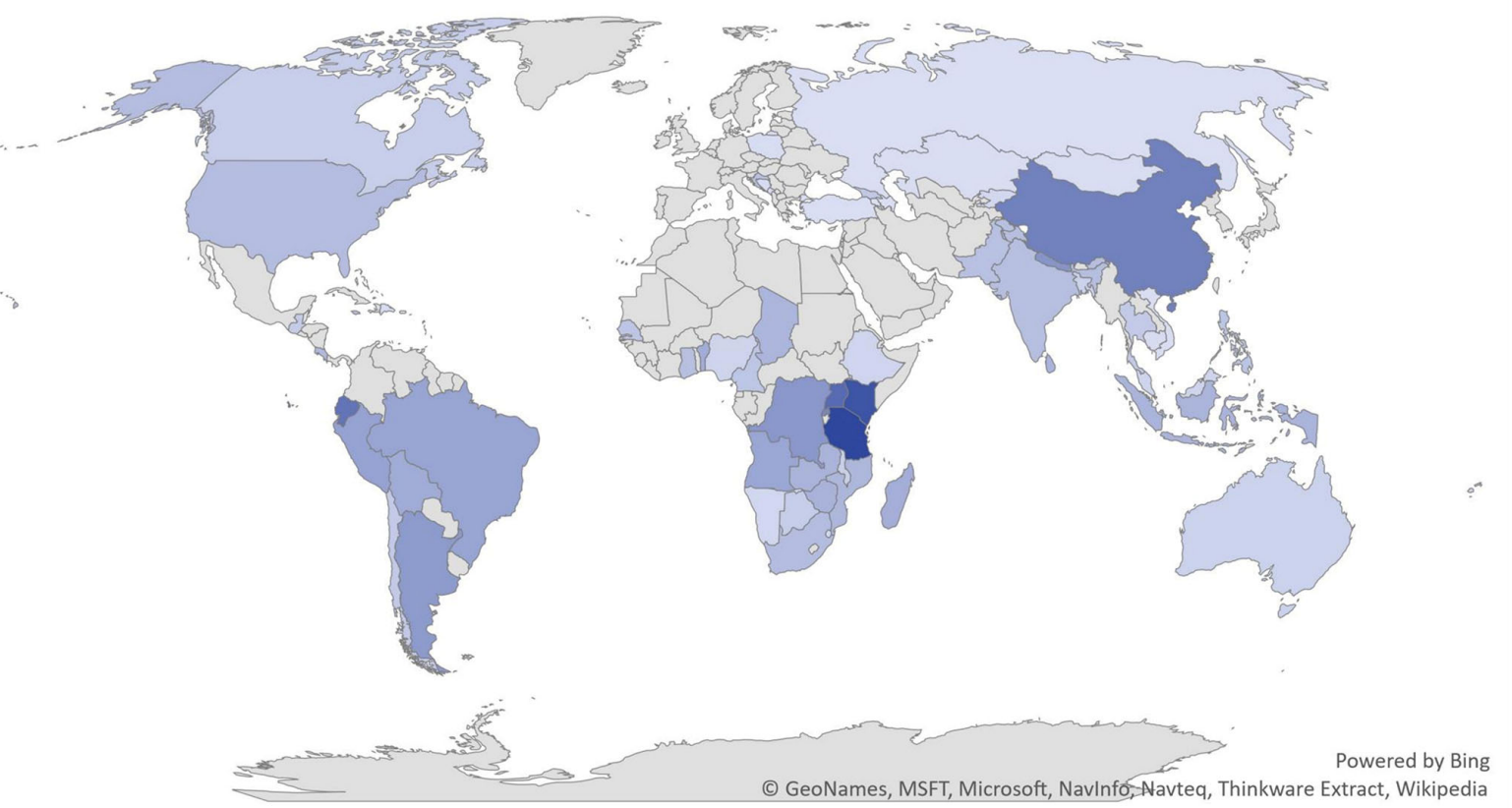

Figure 2. Map of national park entrance fees for international tourists by country 
Table 4. National park entrance fees for international tourists by country

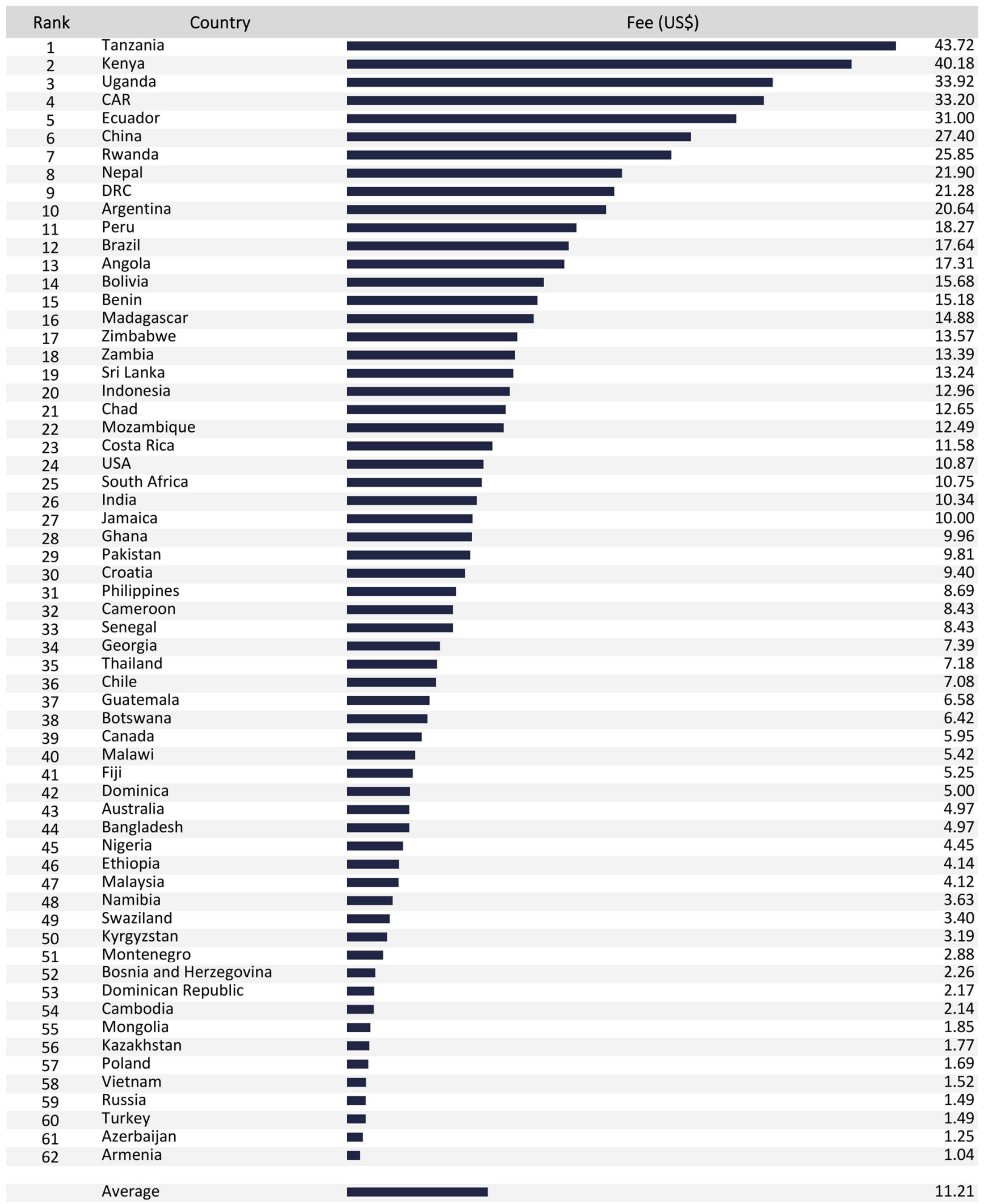


Costa Rica's fee at US\$11.58 being closest to this average.

These fee amounts are all relatively low when compared with an average daily spend of US\$165 for European middle to higher income tourists. This raises the issue of the price elasticity of demand for park visitation. Pagiola et al. (2002) noted that demand for entry to nature-based tourism sites tends to be relatively inelastic (i.e. elasticity between $\mathrm{o}$ and -1 ) as they are a small portion of overall trip costs and are influenced by the availability of substitutes (where unique sites are associated with lower elasticities). Tanzania and Kenya would be typical countries where one would expect to find particularly low elasticities among overseas visitors as their iconic national parks offer Big Five safari experiences and as reaching them is generally associated with high total travel costs. The relatively higher fees in these countries are thus consistent with expected elasticities. It goes without saying that there are numerous other factors and nuances at play in determining these fee levels, such as those outlined in the Introduction.

Entrance fees for international tourists show a similar overall pattern to indices of affordability for entrance fees for citizens when countries are grouped by income, but with a lower degree of difference between country groupings. International tourists to national parks in low-income countries pay an average entrance fee of US\$20 (Table 5). This is twice as high as the average fee paid in both lower middle and upper middle-income countries (both just under US\$10), and four times as high as the average fee paid in high-income countries (US\$5). Lower income countries are thus able to generate substantially more revenue per person from entrance fees than higher income countries.

The regional grouping exercise reveals that East Africa (US\$29.6), China (US\$27.4) and Central Africa (US\$20.4) are the three most expensive regions for international tourists entering national parks, while Russia (US\$1.5), Central Asia (US\$2.1) and the Caucasus (US\$2.8) are the three least expensive regions (see Table 6). The latter three regions share a common history as they all belonged to the Soviet Union prior to its dissolution in 1991. Elements of their shared culture, and particularly an emphasis on state provision of public services, may be a key factor influencing fee levels today. The amount of variation within regions is highest in the Caucasus and in Southeast Asia and lowest in Oceania and South America, as evidenced by the coefficient of variation.

Table 5. National park entrance fees for international tourists by income-level groupings

\begin{tabular}{|c|c|c|c|}
\hline Income group & Average Fee US\$ & \multicolumn{2}{|c|}{$\begin{array}{c}\text { Coefficient of } \\
\text { variation }\end{array}$} \\
\hline Low income & & 19.71 & 0.61 \\
\hline Lower middle income & & 9.34 & 0.78 \\
\hline Upper middle income & & 9.35 & 1.08 \\
\hline High income & & 4.91 & 0.31 \\
\hline
\end{tabular}

Table 6. National park entrance fees for international tourists by regional groupings

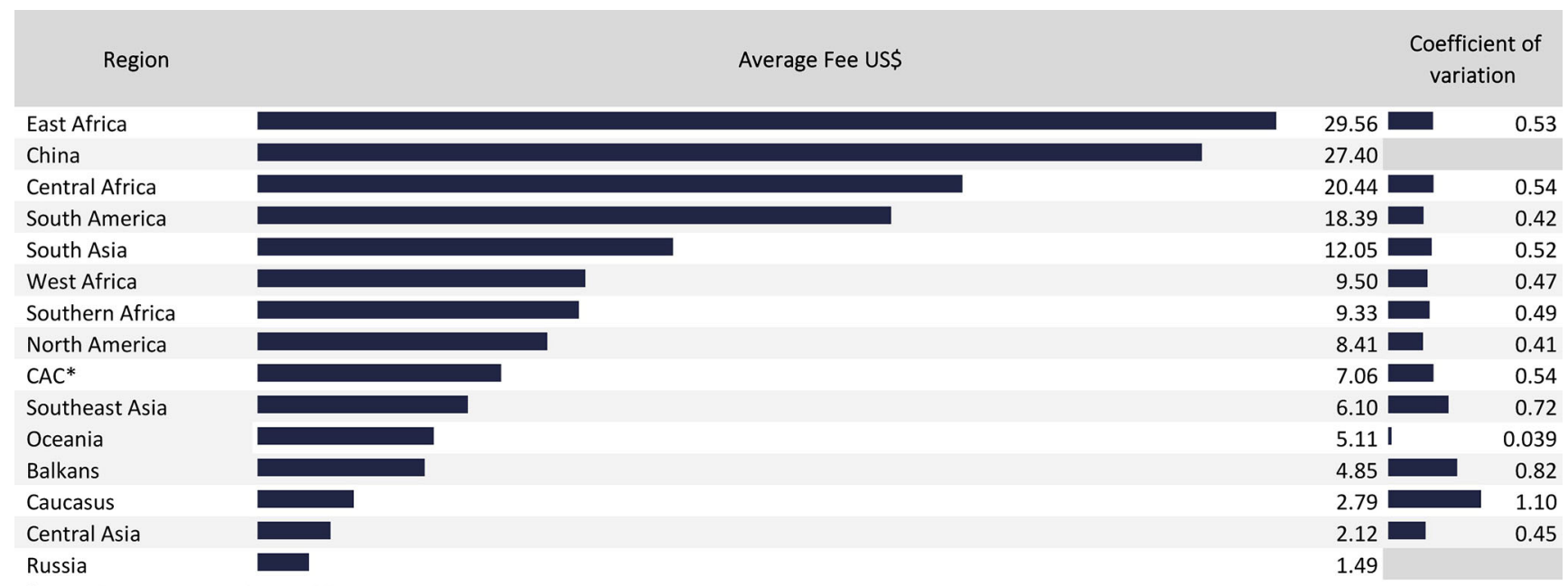

*Central America and the Caribbean 


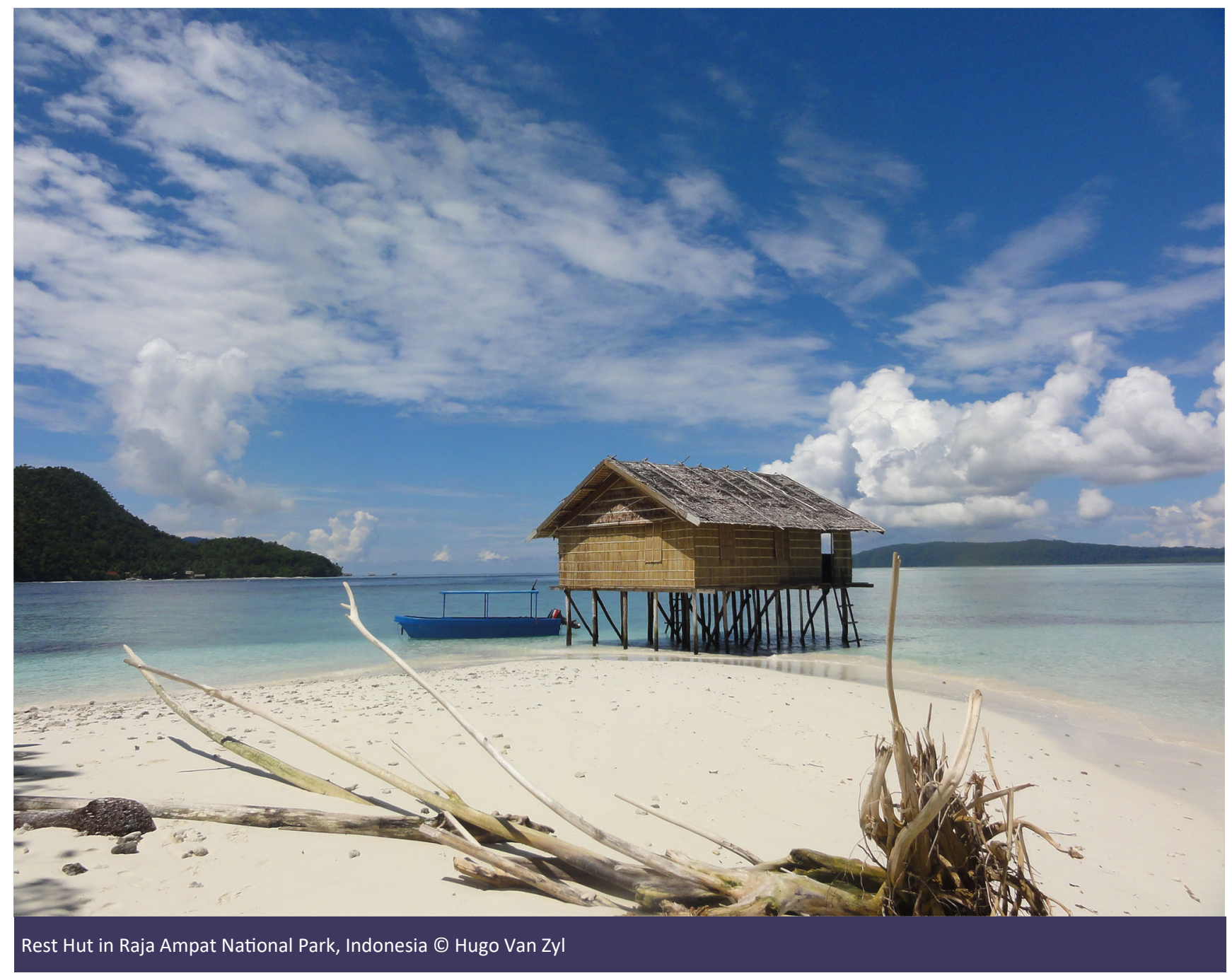

\section{CONCLUSION}

The global benchmarking data in this article provides a useful reference point for setting PA entrance fees. As well as giving a basic understanding of what other (potentially competing) countries are charging for entry, such information can be used as an entry point to encourage stakeholder discussion about the various considerations and trade-offs that should guide pricing. The article has also highlighted the issue of affordability, a relatively under-researched yet clearly important consideration in fee setting. The following broad conclusions can be drawn from the analysis:

National park entrance is substantially less affordable to citizens in lower income countries when compared to those in higher income countries. This has equity implications and is one of the factors that may supress visitation rates, thereby reducing the degree to which people are likely to attach value to, and be willing to support, national parks. It also has potential relevance to debates around the extent to which parks should be managed and financed with the interests of citizens in mind.

Entrance fees for international tourists are generally higher for national parks in lower income countries although the variation is not as great as that associated with affordability to citizens. It seems fair that international tourists would incur higher fees visiting national parks in low-income countries as compared to high-income countries, given that low-income countries generally have a smaller tax base from which to fund national parks. This tends to increase their reliance on tourism earnings. It is interesting to note that lower middle-income countries and higher middle-income countries charge, on average, similar levels of fees for international tourists. There may be scope to revise fee structures so that lower middle-income countries charge international tourists relatively more, although this should be investigated on a case-by-case basis and 
preferably with the aid of market research including willingness to pay studies.

The findings provide further support for differentiated fees for citizens and international tourists, from a relative affordability perspective. This can be added to the other arguments for differentiated fees such as revenue maximisation and fairness.

While comparative fee levels in other countries and relative affordability for citizens provide useful benchmarks or reference points, it is also important to consider other key factors when setting PA entry fees. Of particular importance is the 'quality' of the PA experiences as compared to visitor demands and expectations, as this increases visitors' willingness to pay and associated price elasticities. If PA entrance fees are being considered as a component of funding and financial sustainability, issues of revenue retention and administration are critical concerns.

\section{ENDNOTES}

${ }^{1}$ These are sometimes also referred to as 'site-based' or commercial revenues.

${ }^{2}$ There are very few instances indeed where national protected areas systems receive no budget allocation at all from central government, or are expected to cover all of their own income. This is the case even though public budgets are in many cases extremely low, and many PAs are being increasingly pushed to incorporate cost recovery principles into their pricing and budgets. One region where central government budgets to PAs are very low or non-existent is in former Yugoslavian countries. In Montenegro, for example, PA categories other than national parks receive no transfer at all from national government (Emerton et al., 2011). Until a decade or so ago, a similar situation held in Macedonia; most PAs lacked a dedicated budget for either capital or operational expenditures, and there was no central government allocation to nature protection activities (Emerton, 2010).

${ }^{3}$ According to Buckley (2003: 71): “There are innumerable different mechanisms and models for visitor fees; and optimal fee structures, rates, collection mechanisms and allocation depend on the political, legal, economic and social context in

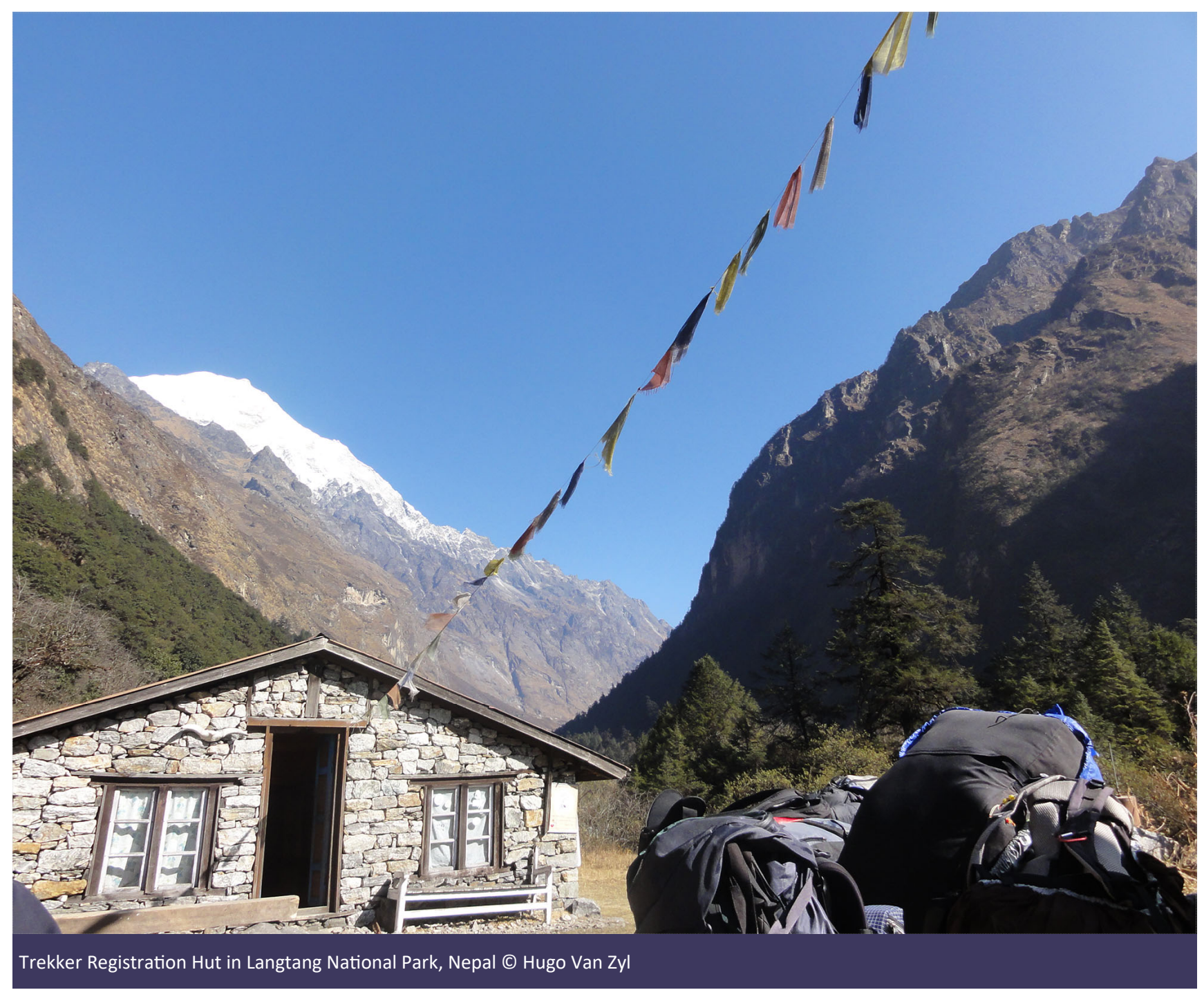


which each park management agency operates."

${ }^{4}$ Some countries charge differentiated fees for non-citizens that are residents (e.g. expatriates) or are citizens of regional country groupings (e.g. SANParks charges lower entrance fees to citizens of Southern African Development Community (SADC) countries in some parks). Where these distinctions were found, data gathering focused on fees applicable to overseas international tourists.

${ }^{5}$ On the whole, we found that collecting this data was substantially more challenging and time-consuming than we expected.

${ }^{6}$ Average daily tourist spending was estimated using data for Europeans travelling abroad (EU, 2017).

${ }^{7}$ Low income $=\leq$ US\$1,005 GNI/Per Capita, upper middle income $=$ US\$1,006 - 3,955 GNI/Per Capita, lower middle income $=$ US\$3,956 -12,235 GNI/Per Capita and high income = $\geq$ US\$12,236 in current US\$ terms.

${ }^{8}$ Estimate based on a 2015 average in-country spend of EUR 89/ day for Europeans travelling abroad (from EU, 2017) adjusted for inflation and converted to US\$115/day plus US\$50/day for travel to the destination (total transport cost of US\$700 spread over a 14-day trip for the average tourist travelling an average distance to a foreign country). The European in-country average spend was derived from middle-income countries such as Bulgaria, Hungary and Romania as well as higher income countries such as France, Germany and Spain.

${ }^{9}$ An elasticity of -1 implies that any increase in price would result in a proportional decrease in demand and an elasticity of 0 would mean that demand would be unaffected by an increase in price. Some examples of elasticity estimates include a relatively high -0.68 for foreign day-visitors to Costa Rican national parks reflecting the relatively high substitutability between the parks and other areas of natural beauty (Alpizar, 2006) and a lower -0.3 for foreign scuba-divers in Indonesia, Thailand and Malaysia (Pascoe et al., 2014).

${ }^{10}$ Low-income countries include Benin, CAR, Chad, DRC, Ethiopia, Madagascar, Malawi, Mozambique, Nepal, Rwanda, Senegal, Tanzania, Uganda and Zimbabwe. Lower middleincome countries include Angola, Armenia, Bangladesh, Bolivia, Cambodia, Cameroon, Georgia, Ghana, Guatemala, India, Indonesia, Kenya, Kyrgyzstan, Mongolia, Nigeria, Pakistan, Philippines, Sri Lanka, Swaziland, Vietnam and Zambia. Upper middle-income countries include: Argentina, Azerbaijan, Bosnia and Herzegovina, Botswana, Brazil, China, Costa Rica, Croatia, Dominica, Dominican Republic, Ecuador, Fiji, Jamaica, Kazakhstan, Malaysia, Montenegro, Namibia, Peru, Russia, South Africa, Thailand and Turkey. High-income countries include Australia, Canada, Chile and Poland.

${ }^{11}$ Countries categorised under the Balkans include Bosnia and Herzegovina, Croatia and Montenegro. Countries categorised under the Caucuses include Armenia, Azerbaijan, Georgia and Turkey. Countries categorised under Central Africa include Angola, Cameroon, CAR, Chad and the DRC. Countries categorised under Central America and the Caribbean include Costa Rica, Dominica, Dominican Republic, Guatemala and Jamaica. Countries categorised under Central Asia include Kazakhstan, Kyrgyzstan and Mongolia. Countries categorised under East Africa include Ethiopia, Kenya, Rwanda, Tanzania and Uganda. Countries categorised under North America include Canada and the USA. Countries categorised under
Oceania include Australia and Fiji. Countries categorised under South America include Argentina, Bolivia, Brazil, Chile, Ecuador and Peru. Countries categorised under South Asia include Bangladesh, India, Nepal, Pakistan and Sri Lanka. Countries categorised under Southeast Asia include Cambodia, Indonesia, Malaysia, Philippines, Thailand and Vietnam. Countries categorised under Southern Africa include Botswana, Madagascar, Malawi, Mozambique, Namibia, South Africa, Swaziland, Zambia and Zimbabwe. Countries categorised under West Africa include Benin, Ghana, Nigeria and Senegal.

\section{ABOUT THE AUTHORS}

Hugo van $\mathbf{Z y l}$ is the founder and director of Independent Economic Researchers, a consultancy focusing on applied environmental resource economics and finance, socio-economic impact assessment and project appraisal. He has extensive international experience contributing to biodiversity conservation programmes, environmental authorisation processes, protected areas ecosystem services valuations, investment cases, cost-benefit analysis and sustainable financing strategies. From a policy perspective, he has provided economic inputs and guidance to biodiversity conservation, climate change, EIAs, mine closure funding and water resource management policy. Key initiatives to which he has contributed include The Economics of Ecosystems and Biodiversity (TEEB), ValuES and the Biodiversity Finance Initiative (BIOFIN).

James Kinghorn conducts research in the field of environmental economics. He has spent the past four years at Independent Economic Researchers, where his focus has been on supporting strategic processes surrounding climate change mitigation and adaptation, biodiversity finance and offsets guidance, as well as project appraisal at various scales, particularly where ecosystem services valuation is required. James is especially interested in novel and experimental approaches to all phases of the research process, including question formulation, data collection and analysis, and the presentation of findings.

Lucy Emerton is an environmental economist specialising in ecosystem valuation, conservation finance and incentive mechanisms. Over the last 30 years she has worked as technical advisor to a wide range of government, non-governmental, private sector, bilateral and multilateral organisations across almost 70 countries worldwide, including establishing and leading IUCN's environmental economics programmes in Africa and Asia. Lucy is currently Conservation Economics and Finance Director of the Environment Management Group, a consultancy group and think-tank providing business planning advice and technical support in 
environmental sustainability to the corporate sector, governments and international agencies.

\section{REFERENCES}

Adams, C., da Motta, R.S., Oritz, R.A., Reid, J., Aznar, C.E. and de Almeida Sinisgalli, P.A. (2008). The use of contingent valuation for evaluating protected areas in the developing world: Economic valuation of Morro do Diabo State Park, Atlantic Rainforest, São Paulo State (Brazil). Ecological Economics 66: 359-370 [online]. Available at: doi:10.1016/ j.ecolecon.2007.09.008 (Accessed: 9 July 2018).

Alpizar, F. (2006). The pricing of protected areas in nature-based tourism: A local perspective. Ecological Economics 56, 294307 [online]. Available at: doi:10.1016/j.ecolecon.2005.02.005 (Accessed: 9 July 2018).

Balmford, A., Green, J., Anderson, M., Beresford, J., Huang, C., Naidoo, R., Walpole, M. and Manica, A. (2015). Walk on the Wild Side: Estimating the Global Magnitude of Visits to Protected Areas. PLoS Biol 13(2) [online]. Available at: doi.org/10.1371/journal.pbio.1002074 (Accessed: 9 July 2018).

Banerjee, O., Cicowiez, M., Ochuodho, T., Masozera, M., Wolde, B., Lal, P., Dudek, S. and Alavalapati, J.R.R. (2017). Financing the Sustainable Management of Rwanda's Protected Areas. Centro de Estudios Distributivos, Laborales y Sociales. Universidad Nacional de La Plata.

Berghöfer, A., Emerton, L., Moreno, A., Rode, J., SchröterSchlaack, C., Wittmer, H. and van Zyl, H. (2017). Sustainable financing for biodiversity conservation - a review of experiences in German development cooperation. UFZ Helmholtz Centre for Environmental Research Discussion Paper 1/2017[online]. Available at: DOI:10.13140/ RG.2.2.23177.75365 (Accessed: 9 July 2018).

Bovarnick, A., Fernandez Baca, J., Galindo, J. and Negret, H. (2010). Financial Sustainability of Protected Areas in Latin America and the Caribbean: Investment Policy Guidance. United Nations Development Programme (UNDP) and The Nature Conservancy (TNC).

Bruner, A.G., Gullison, R.E. and Balmford, A. (2004). Financial Costs and Shortfalls of Managing and Expanding ProtectedArea Systems in Developing Countries. BioScience 54(12): 1119-1126 [online]. doi.org/10.1641/0006-3568(2004)054 [1119:fcasom]2.0.co;2

Bruner, A.G., Gullison, R.E., Rice, R.E. and da Fonseca, G.A.B. (2001). 'Effectiveness of parks in protecting tropical biodiversity'. Science 291: 125-128. doi.org/10.1126/ science.291.5501.125

Buckley, R. (2003). 'Pay to Play in Parks: An Australian Policy Perspective on Visitor Fees in Public Protected Areas'. Journal of Sustainable Tourism 11(1): 56-73. doi.org/10.1080/09669580308667193

Dixon, J.A. and Sherman, P.B. (1991). Economics of protected areas: a new look at the benefits and costs. London, UK: Earthscan

Eagles, P.F.J. (2013). Research priorities in park tourism. Journal of Sustainable Tourism [online]. Available at: DOI:10.1080/09669582.2013.785554

Eagles, P.F.J., McCool, S.F. and Haynes, C.D.A. (2002). Sustainable Tourism in Protected Areas: Guidelines for
Planning and Management. Gland, Switzerland and Cambridge, UK: IUCN.

Edwards, P.J. and Abivardi, C. (1998). The value of biodiversity: where ecology and economy blend. Biological Conservation 83: 239-246. doi.org/10.1016/s0006-3207(97)00141-9

Emerton, L. (2010). Protected Area Financing: Options for Macedonia. Skopje, Macedonia: NDP-GEF/ Ministry of Environment and Physical Planning.

Emerton, L., Bishop, J. and Thomas, L. (2006). Sustainable Financing of Protected Areas: A global review of challenges and options. German Federal Agency for Nature Conservation (BfN) and IUCN - The World Conservation Union. Gland, Switzerland and Cambridge, UK: IUCN.

Emerton, L., Kaludjerovic J. and Jovetic, I. (2011). The Economic Value of Protected Areas in Montenegro. Podgorica, Montenegro: UNDP.

European Union (EU). (2017). Tourism trips of Europeans. Eurostat [online publication], (29 June 2018). Available at: http://ec.europa.eu/eurostat/statistics-explained/index.php? title=Tourism_trips_of_Europeans (Accessed: 5 July 2019).

Flores, M. and Bovarnick, A. (2016). Guide to improving the budget and funding of national protected area systems. Lessons from Chile, Guatemala and Peru. New York, USA: UNDP.

Herath, G. (2000). Entrance Fees as a Suitable Mechanism for Financing Natural Areas in Australia. International Journal of Wilderness 6(2): 35-39.

Hübner, A., Phong, L.T. and Châu, T.S.H. (2014). Good governance and tourism development in protected areas: The case of Phong Nha-Ke Bang National Park, central Vietnam. Koedoe 56(2) [online]. dx.doi.org/10.4102/ koedoe.v56i2.1146

Inamdar, A., de Jode, H., Lindsay, K. and Cobb, S. (1999). Capitalizing on nature: protected area management. Science, 283: 1856-1857. doi.org/10.1126/science.283.5409.1856

lyengar, S., Tay-Teo, K., Vogler, S., Beyer, P., Wiktor, S. and de Joncheere, K. (2016). Prices, Costs, and Affordability of New Medicines for Hepatitis C in 30 Countries: An Economic Analysis. PLoS Med 13 (5) [online]. doi:10.1371/ journal.pmed.1002032

Krug, W. (2000). Nature Tourism and Protected Area Pricing: Lessons learned from Africa. In the Design and Management of Forest Protected Areas: Papers presented at the Beyond the Trees Conference, 8 - 11 May 2000. Bangkok, Thailand.

Lindberg, K. and Halpenny, E. (2001). Protected Area Visitor Fees: Country Review. The Summit Foundation and The International Ecotourism Society and Programme for Belize.

Lindsey, P.A., Nyirenda, V.R., Barnes, J.I., Becker, M.S., McRobb, R., Tambling, C.J., Taylor, W.A., Watson, F.G. and t'SasRolfes, M. (2014). Underperformance of African Protected Area Networks and the Case for New Conservation Models: Insights from Zambia. PLOS ONE 9(5) [online]. doi:10.1371/ journal.pone.0094109

Loomis Hubbell, L.W., Massa, R.J. and Lapovsky, L. (2002). Using benchmarking to influence tuition and fee decisions. New Directions for Higher Education 118. doi.org/10.1002/he.55

Mendes. I. (2003). Pricing recreation use of national parks for an efficient nature conservation: an application to the Portuguese case. Paper presented to the Permanent Seminar of the Department of Economics, Technical University of Lisbon. 
Murakami, Y. and Blom, A. (2008). Accessibility and Affordability of Tertiary Education in Brazil, Colombia, Mexico and Peru within a Global Context. Policy Research Working Paper, Latin America and Caribbean Region: Human Development Sector. Washington, DC: The World Bank.

Nogueira, J.M. and Salgado, G.S.M. (2001). Economia e Gestão de Áreas Protegidas: o caso do Parque Nacional de Brasília. Paper presented at the IV Encontro da Sociedade Brasileira de Economia Ecológica, Belém, PA. November 2001.

Oleas, R. (2008). The Galapagos National Park entrance fee: A global perspective and options for the future. Galapagos Report 2007-2008. Galapagos Conservancy [online periodical], (2008). Available at: https://www.galapagos.org/ about_galapagos/about-galapagos/library/galapagos-reports/ galapagos-report-2007-2008/ (Accessed: 5 July 2018).

Pagiola, S., Martin-Hurtado, R., Shyamsundar, P., Mani, M. and Silva, P. (2002). Generating Public Sector Resources to Finance Sustainable Development: Revenue and Incentive Effects. World Bank Technical Paper No. 538. Washington, DC: World Bank [online]. Available at: https:// openknowledge.worldbank.org/handle/10986/15206 (Accessed: 9 July 2018).
Pascoe, S., Doshi, A., Thébaud, O., Thomas, C., Schuttenberg, H., Heron, S., Setiasih, N., Tan, C.H., True, J., Wallmo, K., Loper, C. and Calgaro, E. (2014). Estimating the potential impact of entry fees for marine parks on dive tourism in South East Asia. Marine Policy 47: 147-152 [online]. doi.org/10.1016/ j.marpol.2014.02.017

South African National Parks (SANParks). (2016). South African National Parks Strategic Plan 2016/17 - 2019/20. Pretoria, South Africa: SANParks.

Spenceley, A. Rylance, A. and Laiser, S.L. (2017). Protected area entrance fees in Tanzania: The search for competitiveness and value for money. Koedoe, 59(1) [online]. doi. org/10.4102/ koedoe. v59i1.1442

Walpole, M., Goodwin, H.J. and Ward, K.G.R. (2001). Pricing policy for tourism in protected areas: Lessons from Komodo National Park, Indonesia' Conservation Biology 15: 218-227. doi.org/10.1046/j.1523-1739.2001.99231.x

Watson, C.L. (2013). An economic analysis of National Park visitation rates. MSc thesis, Montana State University. Montana, USA: Bozeman. 


\section{RESUMEN}

El establecimiento de tarifas de entrada a las áreas protegidas (AP) en los niveles apropiados puede ser muy desafiante. Proporcionamos datos de referencia en una muestra de 62 países y construimos un Índice de asequibilidad (IOA, por sus siglas en inglés), que muestra las tarifas de entrada a las AP en relación con el ingreso per cápita de los ciudadanos ajustado al poder adquisitivo. Utilizando esta medida, los parques australianos son los más asequibles (IOA de 0.10) para los ciudadanos, los de Benín son los menos asequibles (10.69), mientras que Indonesia es el más cercano al promedio mundial de IOA de 2.09. Las AP en los países de bajos ingresos son en promedio 30 veces menos asequibles para los ciudadanos que en los países de altos ingresos. Esto tiene implicaciones en lo que respecta a la equidad, y puede frenar las tasas de visitación, reduciendo así la medida en que los ciudadanos valoran los parques nacionales y están dispuestos a apoyarlos. Las tarifas para turistas internacionales son más bajas en Armenia (US\$1.04) y más altas en Tanzania (US\$43.72), en tanto que Costa Rica está más cerca del promedio mundial (US\$11.21), una proporción relativamente pequeña del gasto diario promedio estimado de US\$165 para los turistas europeos de ingresos medios a altos. Los turistas internacionales que visitan los países de bajos ingresos pagan una tarifa de entrada promedio de US\$20, cuatro veces más que en los países de altos ingresos. Podría decirse que esto es razonable, dado que sus bases de financiación para las AP son mucho más pequeñas y su dependencia mucho mayor en los ingresos del turismo. Nuestros hallazgos apoyan la diferenciación de tarifas entre ciudadanos y turistas internacionales como un medio para equiparar la asequibilidad.

\section{RÉSUMÉ}

Il peut s'avérer difficile de fixer un tarif approprié pour les droits d'entrée des aires protégées (AP). Nous présentons des données comparatives pour un échantillon de 62 pays et avons constitué un index d'accessibilité financière, indiquant les frais d'entrée des AP par rapport au revenu par habitant, ajustés en fonction du pouvoir d'achat des citoyens. Selon cette mesure, les parcs nationaux australiens s'avèrent les plus abordables pour leurs citoyens (index: 0,10), ceux du Bénin sont les moins abordables $(10,69)$, tandis que l'Indonésie se rapproche le plus de la moyenne de l'index à 2,09. Les AP des pays à faible revenu sont en moyenne 30 fois moins abordables pour leurs citoyens que ceux des pays à revenu élevé. Outre les implications en termes d'équité, cela peut faire décroitre les taux de fréquentation, en affaiblissant l'opinion favorable des citoyens envers leurs parcs nationaux et, par voie de conséquence, leur volonté de les soutenir. Les recettes du tourisme international en Arménie se sont révélés être les plus bas (1,04 USD), les plus élevés étant en Tanzanie (43,72 USD), tandis que le Costa Rica se rapproche le plus de la moyenne mondiale (11,21 USD), ce qui constitue en fait une proportion relativement faible des dépenses quotidiennes moyennes estimées (165 USD) des touristes européens à revenu élevé. Les touristes internationaux paient un droit d'entrée moyen de 20 USD dans les parcs des pays à faible revenu, soit quatre fois plus que dans les parcs des pays à revenu élevé. Cette disparité est sans doute justifiée, compte tenu des sources de financement beaucoup plus réduites des pays à faible revenu et de leur forte dépendance au tourisme. Nos conclusions viennent étayer la mise en oeuvre d'une différenciation dans les droits d'entrée entre citoyens et touristes internationaux en tant que moyen d'égaliser l'abordabilité des parcs. 